Generally speaking, the author documents his sources well, albeit minor mistakes happen sporadically ${ }^{7}$ — which is, perhaps, unavoidable, taking into account the range of the work. The Glossary is also accompanied by an extremely useful bibliography of critical works on fantastic literature up to the year 1985 .

The study is impressive both in its ambitions and their execution and its two major shortages are rather predictable. First, it is limited, as it has already been remarked, to English language sources, thus ignoring a lot of interesting ideas that had the bad luck of being conceived in other parts of the world. Second, as the book has been published thirty one years ago, it does not include current developments (such as, by way of example, more recent theories and terms proposed by Farah Mendlesohn ${ }^{8}$ and Brian Attebery ${ }^{9}$ which have already proved quite influential). It is, perhaps, a pity, that Wolfe has not decided to revise and update his work.

Despite these minor — and as it has been suggested — understandable deficiencies, Wolfe's glossary remains an essential position of SF and fantasy criticism and is highly recommended to all scholars and readers confused by the sometimes esoteric and exotic terminology applied in the field.

7 Zgorzelski's proposal mentioned in the previous footnote was presented to English speaking public in SF Studies in 1979 and not in 1967 as the entry on "fantasy" suggests.

8 F. Mendlesohn, Rhetorics of Fantasy, Middletown 2008.

9 B. Attebery, Strategies of Fantasy, Bloomington-Indianapolis 1992.

\title{
Stanisław Krawczyk
}

Uniwersytet Warszawski

\section{What is science fiction for?}

DOI: $10.19195 / 0867-7441.23 .22$

Review: Brian Stableford, The Sociology of Science Fiction, Borgo Press, San Bernardino 1987, 192 pp.

Słowa kluczowe: komunikacja literacka, socjologia fantastyki, socjologia literatury

Keywords: literary communication, science fiction studies, sociology of literature

Sociological interest in science fiction is twofold. ${ }^{1}$ First, researchers look into the fictional depictions of social life. Second, they look into the social context of

1 Numerous examples of both approaches can be found in Arthur Evans' "Histories", [in:] The Oxford Handbook of Science Fiction, ed. R. Latham, New York 2014, p. 49. A useful overview of science-fictional speculations on society has been provided by Brian Stableford in his "Sociology",

Literatura i Kultura Popularna 23, 2017

(C) for this edition by CNS 
fiction, whether that context is distant (politics, economy, culture...) or proximate (editors, writers, critics, readers, conventions, awards...). The first type of interest is prevalent in science fiction studies but the second is somewhat less common. ${ }^{2}$ And even within the context-oriented analyses, Brian Stableford's book is still notable in that it firmly follows the structure of research reports often found in social science: from theory through method to results. It is telling that in a recent SF handbook Stableford's 1987 study is still considered to be one of "the most prominent" pieces in the "sociological work [...] done on science fiction readers and fans". This is in part because "subsequent work has mostly focused on film and television fandom, whose conventions have been more commercial". 3

As a reviewer for a Polish academic journal, I will add that science fiction studies in Poland is still less focused on the social context. This remark may be illustrated with a list of authors who have written monographs taking that context at the most as a minor point of interest. ${ }^{4}$ This in itself should not be considered a drawback of any particular publication, but the net result remains: the social context of science fiction is heavily understudied. There are exceptions, including both original works ${ }^{5}$ and translations, ${ }^{6}$ but they do not change the overall situation, and there are hardly any studies with the aforesaid social scientific structure.

For those reasons, the extended study by Brian Stableford - himself a prolific SF writer - is a rare and valuable example of its kind. This review concerns the book released in 1987 (and reprinted in 2007), disregarding a later chapter

[entry in:] The Encyclopedia of Science Fiction, ed. J. Clute et al., London 2016, http://www.sf-encyclopedia.com/entry/sociology (access: 27.12.2017).

2 Important studies on the context of SF have been conducted by Michael Ashley, Camille Bacon-Smith, William Bainbridge, Mark Bould, John Cheng, Fredric Jameson, John Rieder, Adam Roberts, Sherryl Vint, and Gary Westfahl.

3 A.M. Butler, "Science fiction criticism", [in:] The Science Fiction Handbook, ed. N. Hubble, A. Mousoutzanis, London 2013, p. 189.

4 The list would include Leszek Będkowski, Katarzyna Bocian, Henryk Dubowik, Ryszard Handke, Jerzy Jarzębski, Piotr Krywak, Zdzisław Lekiewicz, Mariusz M. Leś, Adam Mazurkiewicz, Rafał Nawrocki, Andrzej Niewiadowski, Iwona Pięta, Antoni Smuszkiewicz, Andrzej Stoff, and Maciej Wróblewski.

5 A few notable examples: S. Lem, Fantastyka i futurologia, vol. 1, Kraków 1970; D. Guttfeld, English-Polish Translations of Science Fiction and Fantasy: Preferences and Constraints in the Rendering of Cultural Items, Torun 2008; P. Siuda, "In pursuit of pop culture: Reception of pop pulture in the People's Republic of Poland as opposition to the political system - Example of the science fiction fandom", European Journal of Cultural Studies 17, 2014, no. 2, pp. 187-208; A. Wierzchowska, "Literacka subkultura? Polski fandom w latach osiemdziesiątych", [in:] Społeczeństwo polskie w latach 1980-1989, ed. N. Jarska, J. Olaszek, Warszawa 2015, pp. 183-204; J. Kucharska et al., "Negotiating the local and the global in the construction of semiperipheral identity in Polish science fiction and fantasy fandom", Transformative Works and Cultures 19, 2015; A. Nowakowski, Fanzin SF. Artyści, wydawcy, fandom, Poznań 2017.

${ }^{6}$ For instance: V. Graaf, Homo futurus. Analiza współczesnej science fiction, transl. Z. Fonferko, Warszawa 1975; J. Kagarlicki, Co to jest fantastyka naukowa?, transl. K.W. Malinowski, Warszawa 1977. 
which was initially meant as part of a revised second edition. ${ }^{7}$ The book contains the text of the author's doctoral dissertation which was finished in 1978, and the examined material - which is generally related to science fiction in the United States - only reaches the beginning of the 1970s. However, while Stableford himself considered his work to be outdated at the time of publication, his judgment was far too harsh.

$* * *$

The introduction to this six-chapter book offers an interesting, if undeveloped, suggestion that science fiction "deals so frequently with images of the future and with alternative modes of social organization" that it may be unusually "revealing of people's attitudes to social change". 8 The initial chapter reviews the principal approaches to the sociology of literature. The author distances himself from the standpoints that picture literature as a product, understood either as an expression of collective consciousness (György Lukács, Lucien Goldmann, and other Marxist scholars) or as a commodity to be traded in the market (Robert Escarpit). He then proceeds to discuss the communicative functions of literature. ${ }^{9}$ Drawing from the three categories of literary communication defined by Hugh Dalziel Duncan, from the three types of media messages discerned by Gerhardt Wiebe, and from Escarpit's distinction between connoisseur reading and consumer reading, the author proposes a tripartite classification of functions: directive, maintenance, and restorative. It is the analysis of these three functions (or rather, of those aspects of communicative functions that are only found in SF) that is the backbone of the study.

The second chapter explains that the word "directive" is applied to "any communiqué which has a lasting effect on its recipient, giving him new information or affecting his attitudes or dispositions - i.e., any non-disposable communiqué". ${ }^{10}$ The maintenance function is represented in "communiqués used by the reader simply to lend support to ideas and attitudes which he already has". ${ }^{11}$ And the term "restorative" refers to messages that "engage the mind of the recipient in such a way as to »release« him or allow him to »rest« from his confrontation and

7 B. Stableford, "The final chapter of the sociology of science fiction", Foundation 29, 2000, no. 79 , pp. $41-58$.

8 B. Stableford, The Sociology of Science Fiction, San Bernardino 1987, p. 7.

9 Reading this chapter in Poland, one cannot help but notice the analogies between Stableford's take on literature and that of the Polish school of research into literary communication. This is likely to stem from the fact that both were developed at about the same time, and that Polish scholars had been reading similar authors.

10 B. Stableford, The Sociology ..., p. 33.

11 Ibid., p. 36. 
negotiation with the real world". ${ }^{12}$ All three functions have their place in society, and none is more laudable than the rest.

In research practice the directive function can be found in unique aspects of the text, and the other two - in particular the maintenance function - are provided by repetitive elements. Moreover, "in virtually all popular fiction the restorative and maintenance function are served simultaneously [...]. While the maintenance function determines characteristic patterns of resolution and plot structure, the restorative function governs the environment of the story — the literary »decor «". ${ }^{13}$ The relationship between those two functions can be clarified with two more quotations. First, "we choose as worlds to »escape « into those imaginative milieux which permit and encourage the formularistic affirmation of the things we want to believe in, and the things we already do believe in". ${ }^{14}$ Second, readers rarely settle on "worlds in which the kinds of problem-situations which they perceive as relevant to their own lives do not and cannot arise". Instead, they habitually pick "worlds in which those kinds of problem-situations (often exaggerated) can be met and dealt with". ${ }^{15}$

The second chapter also describes Stableford's research material, which consists of science fiction stories and of readers' and writers' commentaries about SF in amateur and professional magazines. In addition, this part of the book presents the nuts and bolts of investigating every communicative function in turn. The chapter ends in an outline of possible "misreadings", or the cases when the function intended by the author is not the one that the text actually serves in the act of reading.

The communicative functions are temporarily removed from the foreground in the third chapter, which is devoted to the publishing evolution of science fiction - mostly in the United States - from the late nineteenth century to the early 1970s. Stableford writes about the advancement of proto science fiction in the late nineteenth century; the upheaval in the SF market in the late 1930s; and the changes that took place after the Second World War. Several publishing forms are discussed: dime novels, pulp magazines, and hardback and paperback books. The chapter is a useful summary but it is hardly a necessary element of the book and can thus be considered one of its weak points.

The same can be said about the fifth chapter, which is an overview of four SF themes: machines, aliens, visions of society, and the evolution of superhuman capabilities. Although the sixth chapter returns to some points raised here, most of this historical analysis - while certainly interesting in itself — is not directly relevant to the study of communicative functions.

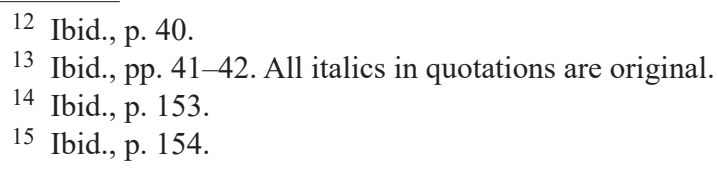


The fourth and sixth chapters are crucial to Stableford's analysis of communicative functions in science fiction. They need to be examined together because important parts of the argument in the fourth chapter are hardly understandable without reference to the later parts of the book, which must be judged as a fairly serious compositional error.

In the fourth chapter the expectations of science fiction readers are analyzed. More concretely, Stableford inspects the expressions of enthusiasm and disappointment; the definitions of the genre; and the statements concerning the function and value of SF. The studied texts are not examined systematically, as in various methods of social scientific analysis which rely on the thorough coding of carefully defined textual units. Instead, they are used as a basis for the interpretive construction of Weberian ideal types.

Proceeding in this way, the author presents the typical directive effect of science fiction as a "perspective shift". ${ }^{16}$ Yet the contents of this change in perception are only explained unambiguously in the sixth chapter:

What seems to be involved is a re-ordering of the context in which ideas relating to science and technology are held, emphasizing certain aspects very heavily: the image of man as a relatively insignificant creature in a vast and complex universe; gadgets as instances of ongoing technological effort leading toward the total human control of the environment. ${ }^{17}$

Numerous autobiographical comments examined by Stableford suggest that this perspective shift typically happened in socially isolated teenagers who considered themselves to be unlike ordinary people. The initial contact with science fiction could alleviate this feeling of alienation because an emblematic SF fan "tends to obtain his sense of identity from his notion of how he relates to a concept of the universe at large [...] instead of from his notion of how he relates to other human beings". ${ }^{18}$ However, one of the likely explanations is that science fiction worked that way "by justifying the sense of being different and apart rather than remedying the situation". ${ }^{19}$ (Notably, these remarks were not equally valid for all SF readers: "A spectrum extends from the most fanatical enthusiast to the reader who enjoys science fiction occasionally [...] Within that spectrum everything is a matter of degree"20).

Science fiction could also have a directive effect on long-term readers. This influence would rely on what Stableford calls "affective aggression", or the "abil-

16 Ibid., p. 72.

17 Ibid., p. 146.

18 Ibid., p. 94. As noted by Stableford, this approach does not require the assumption that SF fans are unusually intelligent or imaginative. And it may be that highly intelligent fans have been drawn to the genre by the feeling of isolation rather than by intellect itself.

19 Ibid., p. 147. This is one of the few overtly value-laden comments in the book.

20 Ibid., p. 94. 
ity to call attention urgently to new concerns, and to force some kind of emotional response hitherto". ${ }^{21}$ SF does not have a good track record in anticipating social problems. Once those appear in the non-fictional world, though, writers respond by amplifying them, which is "not simply a reflection [...] but a reaction". 22 This exaggeration allows the genre to appeal strongly to the readers' emotions. At the same time, "[t] he warnings and social criticisms" here "are rather more general and less immediate than those contained in satire". ${ }^{23}$

For the people who already have some experience with SF, the genre could also have a characteristic maintenance function. In this regard science fiction is anomalous in that its history shows relatively frequent, if not actually revolutionary, changes in plot patterns. In early pulp SF resolving conflicts with marvelous inventions supported the idea that technological innovation could bring answers to existential and social problems. Then this faith declined, which is visible in the evolving role of machines in science fiction. In the 1950s another common resolution was the use of a spaceship as a means of escaping from a doomed civilization and starting a new one elsewhere. The patterns of the 1960s were less formulaic but some significant plot conclusions involved the uplifting contact with an alien race or the evolution of superhuman capabilities. These conclusions strengthened the readers' "conviction that the ideal state of being is to be sought not in terms of a better place $[\ldots]$ or $[\ldots]$ time $[\ldots]$ but in terms of a »better adjusted « or »healthier« state of mind". 24

Unfortunately, Stableford's explanations of how the maintenance function might work in SF are very vague. First, he claims that what was maintained in general was "a special attitude to the world" or the genre's "basic perspective",25 but he never clarifies what he means by that. Second, we are not told exactly how the instability of plot patterns is supposed to have supported the said attitude. Third, in this case there is no clear differentiation between beginners and experienced readers. And fourth, the author does not specify how particular perspectives sustained by concrete historical resolutions were related to the aforementioned general maintenance function of SF. Due to all that, the treatment of this communicative function is ultimately disappointing, even though in a few specific cases the author's analyses are quite convincing.

In analyzing the restorative function of SF, Stableford demonstrates how its fictional worlds worked as settings in which the maintenance effect could be achieved. For instance, he discusses the technological landscapes of some early science fiction "in which triumph by technological innovation becomes both possible and »valid «", allowing adolescent readers to deal with their feeling of

$\begin{array}{ll}21 & \text { Ibid., p. } 148 . \\ 22 & \text { Ibid., p. } 110 . \\ 23 & \text { Ibid., p. } 148 . \\ 24 & \text { Ibid., p. } 152 . \\ 25 & \text { Ibid., p. } 80 .\end{array}$

Literatura i Kultura Popularna 23, 2017

(C) for this edition by CNS 
vulnerability through "technological invention and the attainment of intellectual security via scientific knowledge". ${ }^{26}$ As another example, many stories of the 1960 s were set in worlds where alien beings could integrate harmoniously into their environment, thus being able to guide humans to similar mystical states.

$* * *$

The three main disadvantages of the study have already been named: the detachment of the third and fifth chapters from the central argument, the limited comprehensibility of the fourth chapter, and the imprecise treatment of the maintenance function. However, Stableford's book is still a commendable piece of sociological work. It does not constrain itself to bibliographical references already customary in the field of science fiction studies. Furthermore, the theoretical background is closely related to the methodology, and practical research decisions are clearly presented and meticulously justified. The study is also remarkable thanks to the diversity of the investigated material, which combines fiction and critical commentary. The differentiation between various groups of readers is welcome, too (although it is not carried out consistently).

This work is an instructive study, useful not just as a source of knowledge on SF's history but also as a theoretical and methodological inspiration for scholars interested in investigating the social dimensions and contexts of science fiction, or of popular literature in general. Perhaps the most obvious research idea stemming from Stableford's analysis would be the application of his framework to the science fiction published since the mid-1970s. In addition, some of the effects that past SF had on its readers may still be viable today. Yes, I have generally written about those effects here in the past tense, under the assumption that it would be rash to make inferences about the 2010s basing only on the material that goes back several decades. But this means that more research is needed to see which of Stableford's conclusions might apply to our time, not that we can be certain they are all no longer valid.

A review published in 1988 called Stableford's work "still the best sociological study around"27. Even now, in 2018, that assessment may not be far from the truth.

26 Ibid., p. 154.

27 N. Barron, "Still the best sociological study around", Science Fiction Research Association Newsletter April 1988, no. 157, p. 42. 